\title{
A realidade coisificada e reificada em tempos de manifestações sociais
}

\section{The reality reified and reified in times of social manifestations}

\section{Renato Tadeu Veroneze*}

Resumo: O objetivo central deste artigo é refletir sobre o cotidiano e o processo de alienação/reificação da vida social que tem gerado um clima de revolta em todo o mundo. Para tanto, recuperamos o conceito de alienação produzido pela sociedade regida pelo capital e pelo modo de produção capitalista. A emergência da sociedade burguesa e o processo de industrialização gerado pela Revolução Industrial proporcionaram a ascensão do reinado da exploração do "homem pelo homem". Por meio das análises referendadas pela Teoria Social de Marx, buscase entender a complexidade da vida social e o processo de alienação/reificação em tempos modernos.

Palavras-chaves: Cotidiano. Alienação/reificação. Mobilizações sociais.

\begin{abstract}
The main aim of this paper is to discuss on the everyday and the process of alienation/reification of social life that has generated a climate of revolt around the world. Therefore, we recover the concept of alienation produced by society governed by capital and the capitalist mode of production. The emergence of capitalist society and the process of industrialization generated by the Industrial Revolution produced, provided that the increase the government's exploitation of the "man by man" Supported by the analysis of Marx's Social Theory, try to understand the complexity of social life and the process of aleination/reification in modern times.
\end{abstract}

Keywords: Everyday. Alienation/reification. Social mobilizations.

Recebido em: 11/11/2011. Aceito em: 20/11/2012.

\footnotetext{
"Possui graduação em Serviço Social pelo Centro Universitário da Fundação Educacional Guaxupé - UNIFEG , Pós-Graduado em Educação, Metodologia e Didática do Ensino Superior - UNIFEG, Pós-Graduando em Filosofia Contemporânea, pela PUC-MINAS, Poços de Caldas/MG, Mestre em Serviço Social, PUC/SP (2013) e Doutorando em Serviço Social pela PUC/SP.E-mail: rtveroneze@hotmail.com
} 


\section{Introdução}

Em tempos modernos, no auge do desenvolvimento do modo de produção capitalista, da tecnologia e da globalização, as relações sociais, os sistemas de governo e as políticas públicas apresentam-se peremptoriamente subsumidos totalmente ao apelo do capital e à barbárie capitalista "omnilateral e polifacética" (NETTO, 2010, p. 31). Nessa ótica, a vida social acaba sendo regida pela lógica do capital, e as relações e inter-relações sociais se apresentam totalmente coisificadas e reificadas.

Tendo como exemplo o filme Tempos Modernos, de Charles Chaplin, podemos justamente fazer uma crítica feroz ao processo acelerado da "modernização" e industrialização/robótica da sociedade globalizada, mostrando como a vida cotidiana e as relações sociais estão constantemente sendo engolidas e subjugadas pela lógica capitalista e pela mercantilização da coisa pública e dos direitos civis, políticos e sociais.

A explosão das massas que temos presenciado nos últimos anos em várias partes do mundo, sem sombra de dúvidas, nos faz refletir sobre antigos conceitos, velhos dilemas e concepções teóricas que pareciam hibernar num sono letárgico das utopias do passado.

A história tem demonstrado que as utopias de uma vida e de um mundo melhor, descritas, muitas vezes, em obras que atravessaram os séculos, como a República - de Platão, A Utopia - de Thomas More, a Cidade do Sol - de Campanela ou a Nova Atlântida - de Francis Bacon, espelhavam uma crítica ao modelo de sociedade em que viviam e preconizavam a necessidade de mudanças no modo de ser, de pensar e de agir. Na história das teorias sociais, somam-se exemplos de utopismos românticos como estes.

Estamos de acordo com Szacki (1972) quando aponta que a possibilidade da utopia caminha junto com a necessidade de escolha. Escolher entre algo que já está determinado é uma nova possibilidade, um ideal a ser projetado: "[...] mais próximo do pensamento utópico é sem dúvida o revolucionário que luta para destruir as relações dominantes e construir novas no lugar" (SZACKI, 1972, p. 15).

É esse sentido revolucionário que nos faz pensar a realidade dos dias atuais. Logicamente, para que se possam ter condições objetivas para desenvolver as potencialidades humanas ou, como diriam Marx e Engels (2007), para que o humano possa fazer história, é preciso que as necessidades mais primárias sejam satisfeitas: comer, beber, morar, vestir, andar, dentre outras coisas.

Tais necessidades têm sido ameaçadas substancialmente na atualidade. Todos os dias presenciamos e vivenciamos o resultado de crises cíclicas próprias do sistema capitalista, que geram um desconcerto de uma sociedade moderna, cosmopolita e civilizada, mas que convive placidamente com a realidade das violências, do arbítrio, da iniquidade, da corrupção, da acumulação desenfreada, das mazelas humanas, enfim, num descompasso entre a representação fantasiosa do real e a realidade.

Em várias partes do mundo, vemos renascer a utopia de um mundo diferente, de uma vida melhor. Manifestações pacíficas ou violentas demonstram "agendas mal resolvidas, contradições e paradoxos" (ROLNIK apud MARICATO et. al., 2013) que desde 2011 povoam as ruas numa "eclosão simultânea e contagiosa de movimentos sociais de protestos com reivindicações peculiares em cada região" (CARNEIRO apud HARVEY et. al., 2012): "[...] a cidade não é só o palco das lutas, mas é também aquilo pelo que se luta" (BRITO; OLIVEIRA apud MARICATO et. al., 2013, p. 69).

A velha questão social aponta para antigos e novos desafios que os governantes buscam "remediar" ou "remendar" por meio de ações focais e minimalistas para encobrir as desigualdades sociais que assolam a vida de milhares de pessoas ao redor do mundo.

Essas manifestações apontam para uma nova sociabilidade, num esforço coletivo para romper com a cultura histórica da meritocracia, do particularismo, do mercantilismo e do clientelismo que mascara as ações governamentais ou até mesmo as organizações e instituições dos setores públicos e privados que, por meio de ações reducionistas, minimalistas ou fundamentalistas, buscam a redução das desigualdades regionais e setoriais ou a conservação do status quo pela força, pela violência e pelo autoritarismo.

Ao fazer uma análise de conjuntura dos principais fenômenos que imperam para a crise do modelo vigente, o Prof. Dr. José Paulo Netto, no texto Uma face contemporânea da barbárie (NETTO, 2010), nos traz importantes 
elementos para entendermos os principais fatores que possibilitaram esse clima de revolta e indignação revolucionária que tomou as ruas e que são analisadas nos textos de vários autores mundialmente conhecidos e copilados no livro OCCUPY: movimentos de protesto que tomaram as ruas, publicado pela editora Boitempo (HARVEY et. al., 2012), e no recente livro, também editado pela mesma editora, Cidades Rebeldes: passe-livre e as manifestações que tomaram as ruas do Brasil (MARICATO et. al., 2013).

Nesses textos, podemos ter uma pequena amostra do que vem acontecendo na atualidade e que, sem sombra de dúvida, refletem significativamente na vida da população mundial, sobretudo nas vidas que estão à mercê dos poderes públicos e da proteção social do Estado.

Diante desse cenário, buscaremos nesse artigo exemplificar como o cotidiano é constantemente bombardeado por acontecimentos que afetam a vida social direta ou indiretamente. Para tanto, nos apropriamos inicialmente de algumas manchetes corriqueiras dos dias atuais para apontar o estágio atual da humanidade e alguns dos principais problemas que têm afetado a vida cotidiana em nível mundial.

Também, para maior compreensão, recuperaremos o conceito de alienação, no intuito de visualizarmos o processo de coisificação e reificação da vida social e das relações sociais. Finalmente, buscaremos esboçar como os fatos corriqueiros, às vezes sem a menor importância, afetam o cotidiano das pessoas nas mais extremas localidades do mundo.

\section{A "BABEL" capitalista dos tempos modernos: "SALVE-SE QUEM PUDER!"}

Nas conferências de abertura do III Simpósio Mineiro de Assistentes Sociais, realizado em Belo Horizonte, nos dias 07, 08 e 09 de junho do ano de 2013, o diapasão que afinava as discussões, buscava analisar as configurações da crise contemporânea e as políticas neodesenvolvimentistas que tendem a "financeirizar"

\footnotetext{
1 Para Leila Paulani (apud NAGOYA, 2012, p. 20) a financeirização "produz uma regime onde a renda produzida é muito baixa, porém, é um sistema rentista, que depende da geração de produtos e de renda para poder extrair o lucro, então é uma contradição muito complicada".
}

as ações e as políticas sociais no interior do Estado. Esse mesmo diapasão compôs a mesa de abertura do VI Simpósio Anual de Serviço Social, realizado na cidade de São Paulo, no dia 12 de maio de 2013.

Esse assunto tem prevalecido nas atuais discussões e preocupado cientistas, pesquisadores, intelectuais, organizações internacionais e nacionais, o poder público e os setores empresariais. Embora os numerosos estudos e relatos sobre a complexidade das "novas expressões" da questão social, sobretudo as que afetam diretamente as populações mais pobres, revelam uma crise cultural, econômica, social e política da sociedade atual.

Em entrevista a Caros Amigos (2012, p. 20-22), Leila Paulani, professora de Economia e Administração (FEA) da Universidade de São Paulo (USP), faz uma análise de conjuntura da crise atual. Mesmo com o seu posicionamento pessimista/reformista, Leila aponta que as crises atuais estão relacionadas à "transformação na forma como o capitalismo está se desenvolvendo, aquilo que alguns economistas chamam de financeirização do processo capitalista" (apud NAGOYA, 2012, p. 20).

Para Leila, desde as décadas de 1970 e 1980 , a riqueza financeira vem crescendo rápida e vertiginosamente, provocando, dessa forma, uma série de transformações, dentre elas, a ascensão do neoliberalismo (apud NAGOYA, 2012, p. 20). O velho dilema analisado por Marx continua a assolar a vida em sociedade. Parafraseando Netto (2001), a pobreza e as desigualdades sociais continuam crescendo na razão direta em que se aumenta a capacidade social de produzir e acumular riquezas.

Assim como nos séculos XVIII e XIX, a sociedade atual vivencia a capacidade de produzir bens e serviços, mas não oferece acesso efetivo para que esses mesmos bens e serviços sejam acessados por um grande número de desprovidos das condições materiais de sobrevivência.

Leila destaca que, dos anos de 1980 para cá, mundialmente falando, acompanhamos constantemente uma série de crises financeiras: "não se fica três ou quatro anos sem enfrentar uma. [...] Não teremos mais paz econômica, vamos viver experimentando crises de tempos em tempos". Também aponta que a crise de 2008 nos Estados Unidos trouxe consequências para 
o Brasil, pois o crescimento econômico que vinha despontando, caiu vertiginosamente de $5 \%$ a $6 \%$ para $0,3 \%$ ao ano, porém, para ela, o Brasil tem hoje uma "situação relativamente confortável, do ponto de vista financeiro" (idem, p. 20-21). Nos dias atuais, vemos que essa zona de conforto tem sido abalada progressivamente.

Outro ponto a destacar é a relação da China que, para ela, "é uma grande incógnita, porque depende dela mesma e dos dirigentes chineses", que vêm aproveitando da situação de crise e investindo especulativamente em diversos países do mundo. É sabido que a força-de-trabalho na China é explorada ao máximo.

Ao se referir ao Brasil, aponta para um crescimento na área das políticas compensatórias, de crédito e de regulação dos juros, o que tem aumentado o poderio da "classe C" (ou da "classe média" de acordo com alguns teóricos) e do consumo. É notório que as políticas de combate à pobreza no Brasil, controversas a parte, têm sido analisadas como populistas, de "assistencialização economicista"2, apesar de alguns avanços. Para finalizar, Leila acredita que "a tendência é que, de tempos em tempos, o mundo passe por crises" (idem, p. 21-22).

Nas palavras do Prof. Dr. José Paulo Netto (2010): o capitalismo é a própria crise. Em suas estratégias neodesenvolvimentistas, os bancos internacionais buscam injetar dinheiro nos setores afetados da economia no sentido de retirar os países ditos de "primeiro mundo" do atoleiro que estão provocando, porém, "[...] os bancos se recuperaram, mas a economia e os países ficaram abandonados" (SADER apud HARVEY, 2012, p. 83).

[...] a crise voltou como bumerangue, tendo agora diretamente os governos como epicentro, pressionados pelo sistema bancário e pelos organismos que expressam seus interesses: FMI e Banco Central Europeu. Primeiro, em 2008, faliram bancos e outras instituições financeiras; depois foram os países, tendo a Grécia como caso paradigmático e que estende sua sombra a quase todos os Estados da zona do euro (idem, p. 84).

\footnotetext{
${ }^{2}$ Não nos cabe aqui defender ou refutar qualquer classificação ou análise das políticas públicas brasileiras na área da Assistência Social, como nas demais áreas, apenas estamos apontando alguns resultados críticos que já aparecem no cenário acadêmico. Em nossa opinião, há verdades e mitos nessa questão.
}

Nesse cenário, só mesmo apelando para a resiliência ${ }^{3}$ ou ao apelo da dramaturgia e dos enredos das telenovelas, que mostram descaradamente a sonegação, os paraísos fiscais, o roubo de documentos, a corrupção, dentre outros assuntos, como se estes fossem apenas enredos de novelas. Por outro lado, enquanto a mídia faz o papel do "mocinho bonzinho", que denuncia e desvela a impunidade e a corrupção, atua como vilã induzindo ao consumismo desenfreado, aos estereótipos mais diversos e ao fetiche do capital.

Numa outra análise, a "Cúpula dos Povos", grande evento realizado na cidade do Rio de Janeiro, Brasil, de 15 a 22 de junho de 2012, Sandra Quinteiro, economista do Instituto Políticas Alternativas para o Cone Sul - PACS, representante da Rede Jubileu Sul Américas, fez uma crítica quanto aos resultados da $R I O+20$ (2012), conferência que reuniu quase 200 delegações de diversos países para discutir as questões ambientais. Sandra destaca que o documento que saiu desse encontro "foi tão rebaixado que, de fato, o que sai daqui fortalecido não é o multilateralismo, mas o poder corporativo" (SÁ; JÚNIA, 2012, p. 36), e conclui que:

A Cúpula dos Povos foi anticapitalista. É urgente e necessária a criação de um novo modelo, minha gente. Não dá, o capitalismo está nos matando, está colocando a vida sob o júdice do lucro. O lucro está acima da vida e de qualquer racionalidade. As áreas que estão preservadas, que estão nas mãos hoje das populações tradicionais do sul, estão sendo mercantilizadas por mecanismos como o mercado do carbono. A Cúpula conseguiu se manifestar contra tudo isso, é uma grande vitória política num momento de muito dissenso e desarticulação. Em um momento também de muita captura corporativa, de grandes ONGs, parte de alguns movimentos que estão no campo e nas florestas ainda um pouco seduzidos pela ideia do pagamento de serviços ambientais e outras coisas mais, mas eu acredito que com a Cúpula isso vai mudar. (idem, ibidem).

O processo de industrialização, mercantilização e globalização do capitalismo, sobretudo

\footnotetext{
${ }^{3}$ De acordo com Junqueira e Deslandes (2003, 228), resiliência é entendida como uma "reafirmação da capacidade humana de superar adversidades e situações potencialmente traumáticas", ou seja, a capacidade de superar frustações e/ou situações de crise e adversidades.
} 
no que diz respeito à competitividade, à imediaticidade $^{4}$, à lucratividade na e da vida social, são características constitutivas do individualismo exacerbado e violento, ou seja, da reificação da vida humana.

Lembrando Heller (1982) temos que imaginar uma sociedade em que todos os homens e todas as mulheres devem buscar lograr uma vida digna sobre a base da liberdade, da fraternidade e da igualdade social: o "que é realmente a revolução se não a transformação profunda da vida dos homens?" (idem, p. 120-121).

O quadro que se apresenta não inclui problemas somente de natureza política, econômica, social e cultural, mas também de caráter ético-moral. Apesar do pessimismo de alguns analistas, do fatalismo de outros, ou mesmo de algumas ações particulares contra a exploração e a reificação da vida humana, ainda assim, torna-se necessário uma revolução radical, revolução essa no modo de pensar, agir e viver.

Também gostaríamos de destacar os acontecimentos na Síria, região característica dos regimes totalitários, extremistas e fundamentalistas. Protestos pós-democráticos, iniciados em março de 2011, têm gerado uma onda de violência e morte naquela região. O número de vítimas tem ultrapassado a casa dos 3.800 , sendo, na maioria, civis. Como se isso não bastasse, as explosões das revoltas no Egito têm gerado um clima de tensão naquele país que repercute mundo afora.

A crise econômica europeia, desde 2011, também tem gerado um clima de descontentamento geral naquele continente e, por sua vez, tem repercutido no mundo inteiro, deixando um rastro de trinta milhões de pessoas no limite entre a "classe média" e a pobreza. Problemas em todos os sentidos que não eram visíveis naquele continente, que historicamente se afirma como "o primeiro mundo", tem alimentado as manchetes nos mais diversos meios de comunicação.

$\mathrm{Na}$ Índia e na África, é corriqueiro recebermos notícias sobre a situação de penúria e

\footnotetext{
${ }^{4}$ Entende-se por imediaticidade o agir humano enquanto resposta ativa e imediata aos acontecimentos do cotidiano, ou seja, "o padrão de comportamento próprio da cotidianidade é a relação direta entre pensamento e ação; a conduta específica da cotidianidade é a conduta imediata, sem a qual os automatismos e o espontaneísmo necessário à reprodução do indivíduo enquanto tal seriam inviáveis". (NETTO apud CARVALHO; NETTO, 2010, p. 67). Grifos do autor.
}

miséria, na qual a vida humana, muitas vezes, é reduzida a barbárie e a condições subumanas. Por outro lado, deparamo-nos com o despautério de Dubai, um exemplo típico entre os extremos: a riqueza absoluta e a miséria radical.

Ainda na África, para escapar das condições deploráveis do pauperismo, "jovens ugandenses" 5 são recrutados pelos Estados Unidos como reforço do aparato de guerra. Os negros, para não morrerem de fome no seu país, dispõem-se a trocarem de lugar com os "combatentes patriotas americanos", que historicamente alimentaram o mercado de Hollywood, já que estes não mais valoram o sentimento de "amor à pátria".

O movimento Occupy, uma verdadeira eclosão simultânea e contagiosa de movimentos sociais, manifestações, rebeliões e protestos em 2011, começou na África, espalhando-se para a Tunísia, Egito, Líbia, lêmen, Espanha, Grécia, Londres, Chile, Estados Unidos e Rússia, com algumas expressões no Brasil. Foi a respostas dos indignados, numa verdadeira amostra de consciência solidária aos acontecimentos que têm estourado em várias partes do mundo desde a aurora do século XXI. O cotidiano tem se constituído num campo de lutas no qual manifestantes populares ficam acuados entre a truculência dos poderes armados e a violência dos Black Bloc.

Tais acontecimentos nos parecem reportar aos idos de 1968, na Primavera de Praga, em que Heller (1982) descreve o profundo sentimento de coletivismo, solidarismo e patriotismo que imperou naquela ocasião. É possível reverter os acontecimentos, porém, ao invés de termos uma "massa" politicamente divergente e desorganizada, precisamos de um movimento organizado: "a alma carece de pré-história" (HELLER, 1982, p. 146).

No Paraguai, pelo menos o que demonstraram as manchetes, a deposição do presidente Fernando Lugo, no dia 22 de junho de 2012, foi um golpe de Estado, comparado ao de Hitler na Alemanha em 1936, visando tão somente os interesses dos grandes latifundiários do país (ZINET; MONCAU, 2012, 10-13). Mais uma vez, lembrando Heller (1982, p. 163), "[...] não é a

\footnotetext{
${ }^{5}$ Matéria veiculada no jornal Le Monde Diplomatique - Brasil, ano 05, $n^{\circ}$ 06, julho de 2012, tendo como título Soldados africanos para guerras norte-americanas (VICKY, 2012, p. 21-23).
} 
bondade humana que transforma a sociedade, mas sim contrainstituições as que transformam os homens e a sociedade".

Importante também destacar a situação do ensino no Brasil: um mercado altamente rentável, onde tanto o ensino, quanto a educação estão a serviço do capital. Especificamente, no âmbito do Serviço Social, o conjunto CFESS/CRESS Conselho Federal de Serviço Social e Conselhos Regionais de Serviço Social, juntamente com outros sujeitos coletivos, tem se posicionado e lutado contra o ensino mercadológico e notoriamente precário e a favor da educação de qualidade.

Dados emitidos pelo CFESS 6 revelam que "no Brasil, o investimento público direto em educação, em relação ao Produto Interno Bruto (PIB), é de $5 \%$ e, desses, apenas $0,7 \%$ é investido no ensino superior" e ainda, de acordo com dados do artigo "Mercantilização do ensino superior, educação à distância e Serviço Social", publicado em 2009, pela professora da Universidade Federal Fluminense (UFF), Larissa Dahmer, "dos 332 cursos de Serviço Social existentes no Brasil, mais de 205 (61,7\%) foram autorizados a funcionar entre os anos de 2003 e 2009, sendo 91,7\% de natureza privada" (CFESS, 2012).

A situação em relação aos outros cursos universitários é igual ou pior. Ainda, o mais tinhoso descaramento não poderia ser demonstrado nas instituições de ensino instaladas e espalhadas pelo Brasil em shoppings center, comprovando vergonhosamente que a educação se tornou "artigo de vitrine" e que deve se adequar aos apelos do capital e do mercado. Netto (2010; 2001) sinaliza que a "questão social" não mudou, mas sim suas expressões.

No que diz respeito à organização das manifestações, esta também foi alterada. Hoje o mundo virtual, cibernético, o mundo do "silício zeros e uns" é que assume o papel do líder revolucionário ou dos partidos. O que presenciamos é "a passagem da serialidade para a explosão das massas que [...] se dá na medida em que a impossibilidade se torna ela mesma impossível" (IASI apud MARINATO, 2013, p. 44).

\footnotetext{
${ }^{6}$ Manifesto emitido pelo CFESS em comemoração ao Dia do/a Assistente Social e lançamento da campanha Serviço Social de olhos abertos para a educação: ensino público de qualidade é direito de todos/as. Disponível em: http://www.cfess.org.br/arquivos/cfessmanifesta_diadoAS2012-site.pdf, Brasília, 15/05/2012.
}

Para Heller (1982), pensamento e ação devem caminhar juntos na vida cotidiana e deveriam se colocar como uma forma de vida, um dever-ser ético e político, uma filosofia revolucionária de vida no intuito de lutar contra a barbárie e violência aos direitos humanos.

A transformação da vida cotidiana, ou seja, de qualquer forma de vida, e de todas as instituições que reproduzem e fixam essa condição de alienação só pode ter lugar baixo no rol das objetivações. Necessitamos buscar uma nova forma de vida, diferente da que já existe. Se estamos insatisfeitos com a forma de vida dada, todos os que a querem transformar devem se juntar para a construção de uma nova sociabilidade, mais justa e igualitária, tanto pelo pensamento, quanto pela ação: "Se você não está satisfeito com o seu povo, troque-o" (BERTOLD BRECHT, 1953 apud KNISPEL, 2013, p. 43).

Enquanto tudo isso acontece, perguntamos: o que fazemos? Buscando responder e finalizar essas exposições, nos apropriamos das palavras do músico e compositor brasileiro José Geraldo Juste (Zé Geraldo) para nos ajudar a refletir e resumir essa questão:

Enquanto esses comandantes loucos ficam por aíl Queimando pestanas organizando suas batalhas/ Os guerrilheiros nas alcovas preparando na surdina suas Mortalhas/ A cada conflito mais escombros/ Isso tudo acontecendo e eu aqui na praça/ Dando miIho aos pombos / Entra ano, sai ano, cada vez fica mais difícil/ O pão, o arroz, o feijão, o aluguel/ Uma nova corrida do ouro/ O homem comprando da sociedade o seu papel/ Quando mais alto o cargo maior o rombo/ Isso tudo acontecendo e eu aqui na praça/ Dando milho aos pombos.[...].

Nessa Babel do "salve-se quem puder", um número considerável de pessoas prefere estar alheio, ou deixar-se submeter aos "reflexos condicionadores" e aos interesses do capital, ou seja, a lógica da alienação e do estranhamento. Portanto, para que possamos pensar a problemática que assola a vida cotidiana na atualidade é preciso recuperar um conceito que parece estar esquecido: a reificação. 


\section{Reificação em tempos modernos: mecanização da vida}

Com a emergência e consolidação do modo capitalista, a alienação se apresenta no campo social e individual. $\mathrm{Na}$ sociedade do consumo e do descartável, esse processo é ainda mais avassalador, como também violento. Em grande medida, induz e provoca condições para que homens e mulheres assumam características inferiores a sua própria condição humano-genérica, ou mesmo, passe a expressar sentimentos, atitudes, hábitos, costumes, culturas e formas de expressões estranhas a sua natureza.

A mídia e a cibernética, não totalmente nem exclusivamente, contribuem para esse processo. Acostumamos a presenciar ou a participar dos realitys shows ou mesmo de programas que, ideologicamente, conduzem à inferiorizarão da natureza humana, num nível tão exacerbado que ficamos a pensar até que ponto o humano pode se sujeitar a essa humilhação para "ganhar um prêmio" ou ao enriquecimento fácil. Esse estado de alienação reflete significativamente na mentalidade coletiva.

O condicionamento ideológico é tão acentuado que as pessoas se sujeitam a passar por situações as mais inesperadas possíveis, literalmente desumanas, que podem ser verificadas nos programas televisíveis, por exemplo: No Limite, Hipertenção, Pânico, Cante se puder, dentre outros, ou a um nível de maquiavelismo, competitividade e individualismo expostos nos realitys shows. Programas como esses são exibidos em várias partes do mundo e, na maioria das vezes, são aplaudidos por grande parte dos telespectadores.

Não estamos aqui fazendo uma apologia à censura ou à liberdade de expressão, mas, sim, buscando exemplificar a que limite de desumanização homens e mulheres se submetem em busca de um enriquecimento rápido e fácil, como também ao poder e ao status que a mídia Ihes oferece.

Há também outras formas de desumanização, como é o caso do trabalho escravo, da exploração do mundo do trabalho, de todos os níveis de violência, do desrespeito aos Direitos Humanos, do mundo do narcotráfico, dos vícios de qualquer natureza, da miséria, da falta de serviços públicos de qualidade, dentre outros.
Em tempos de manifestações, é nos grandes centros urbanos que os problemas se acumulam e são mais visíveis. Apesar de comportar maiores possibilidades de trabalho, a questão salarial não se apresenta como o único fator para alcançar melhores condições de vida. Há a necessidade de outras questões estruturais para esse fim, tais como transporte, habitação, saúde, educação, segurança, saneamento básico, dentre outros fatores primordiais para a vida humana em sociedade: "[...] a cidade não fornece apenas o lugar, o suporte ou o chão para essa reprodução social" (MARICATO et. al., 2013, p. 20), deve, por sua vez, oferecer condições para a vida humana.

As análises contemporâneas dos últimos acontecimentos apontam que as manifestações que tomaram as ruas do Brasil, desde os grandes centros até às cidades do interior, implicam numa indignação geral às agendas mal resolvidas, às contradições e aos paradoxos que se colocam no cerne das revoltas, apontando para um modelo que já esgotou as suas possibilidades de superação.

Os protestos majoritariamente composto por jovens e estudantes, convocados na sua maioria pelas redes sociais e endossados por todos aqueles que se sentem vitimizados por esse sistema excludente e de exploração, demonstram a face dos que lutam contra a consciência alienada/alienante e despertam a utopia que parecia hibernar num sono letárgico sem fim.

Marx e os marxistas já apontavam para o cotidiano alienado ${ }^{7}$ real, concreto e objetivo. Nesse estágio de condicionamento das relações

\footnotetext{
${ }^{7}$ Para Lefebvre (2009, p. 42), a "alienação do homem não é teórica e ideal, ou seja, algo que se representa exclusivamente no plano das ideias e dos sentimentos; ela também é, acima de tudo, prática, e se encontra em todos os domínios da vida prática. $O$ trabalho é alienado, escravizado, explorado, tornado exaustivo e esmagador. A vida social, a comunidade humana, tornou-se dissociada pelas classes sociais, arrancadas de si mesma, deformada, transformada em vida política, enganada e empregada como meio de dominação do Estado. O poder do homem sobre a natureza, do mesmo modo que os bens produzidos por essa potência estão açambarcados, e a apropriação da natureza pelo homem social se transformou em propriedade privada dos meios de produção. O dinheiro, esse símbolo abstrato dos bens materiais criados pela mão do homem (isto é, pelo tempo de trabalho social, meio necessário para produzir esse ou aquele bem de consumo), comanda e domina aqueles que trabalham e produzem. O capital, essa forma de riqueza social, essa abstração (que, em certo sentido, e em si mesmo, é somente um jogo de escritas comerciais e bancárias), impõe suas exigências à sociedade interna, implicando uma organização contraditória da sociedade, ou seja, a escravização e os empobrecimentos relativos da maior parte dela".
} 
sociais e consigo mesmo, é importante trazer à tona o conceito de alienação. Para tanto, nos apropriamos do estudo desenvolvido por Agnes Heller (1978) e de Netto (1981), para entendermos esse processo.

\section{Alienação e reificação no capitalismo: subserviência ao capital}

Acreditamos que Heller (1978) demonstra claramente como as necessidades mais vitais do ser social coisificam-se na sociedade regida pela lógica do capital. Ao estudar profundamente a categoria necessidade nas principais obras de Marx, Heller construiu a sua Teoria das necessidades em Marx que, conjugada com o seu texto Teoria, práxis e necessidades humanas, apresenta um verdadeiro estudo monográfico stricto sensu em que verifica o desfalecimento e a necessidade de reavivar o sujeito revolucionário marxiano - a classe operária para-si. Poderíamos complementar esses estudos como o texto O lugar da Ética no Marxismo (HELLER, 2004, p. 111-121), no qual Heller apresenta a natureza da ética no marxismo e a consciência coletiva.

A discussão que Heller embrenha em torno do conceito das necessidades tem extrema ligação com a categoria valor que, precisamente, constitui o fundamento materialista da consciência ética e política do ser social.

Para suas análises, Heller parte de alguns pressupostos:

1. O trabalhador não vende ao capitalista seu trabalho, mas sim a sua força-de-trabalho;

2. Elaboração de uma categoria geral de "mais-valia"8 (plus-valia) e sua demonstração (benefício, salário e renda do solo (terra) são apenas forma fenomênicas de "mais-valia").

3. Descobrimento do significado de valor-deuso (Marx escreve que as categorias de valor e valor-de-troca não são novas, mas sim que procedem da economia política clássica). (HELLER, 1978, p. 21).

\footnotetext{
${ }^{8}$ Preferimos empregar a expressão "mais-valia" entre aspas por designar uma categoria de análise em Marx. Sendo ela uma categoria, pode conter em si outras formas de interpretações. Originalmente Marx utilizou da terminologia plusvalia, que é utilizada originalmente por Heller, para designar o excedente de trabalho não remunerado pelo capitalista.
}

Heller, fundamentada em Marx, parte da tese de que "o lugar ocupado na [ou dentro da] divisão do trabalho determina a estrutura da necessidade ou ao menos seus limites" (HELLER, 1978, p. 23), apontando, dessa forma, que cada indivíduo se coloca, ou se apresenta, na e para a vida cotidiana como um conjunto de necessidades diferenciadas.

Mas, vai mais além, ao verificar a estrutura das necessidades, Heller demonstra que não é somente a estrutura da divisão do mundo do trabalho que influencia na diferenciação das necessidades e, por conseguinte, na estrutura do valor. Há determinações que antecedem o próprio mundo do trabalho. Em outras palavras, há implicações de todas as ordens que podem impedir que o indivíduo social se insira no mundo do trabalho e não consiga, assim, satisfazer suas necessidades mais prementes por meio de seus próprios esforços: o desemprego estrutura $^{9}$, o caos dos transportes públicos, da saúde, da educação, a questão urbana, enfim, situações e implicações que impossibilitam as pessoas por algum motivo (físico, intelectual, estrutural, social, cultural ou individual) para o trabalho, de uma forma ou de outra atinge direta ou indiretamente a vida das pessoas que vivem em sociedade.

No sistema capitalista, a inserção na divisão sócio-técnica do trabalho é condição sine qua non para a sobrevivência. Desse modo, estando a vida humana à mercê de outrem, ou da proteção do Estado ou da sociedade, ou da oferta de serviço público de qualidade, pode estar fadada a determinações estranhas a vontade individual ou coletiva.

Conforme as indicações hellerianas: "[...] nossas necessidades - e entre elas, sobretudo, as radicais ${ }^{10}$ - são forças materiais que podem ser capazes de transformar nossa sociedade" (HELLER, 1982, p. 138).

Somos eminentemente sujeitos sociais, ou seja, nos constituímos humanos com a internalização das experiências grupais e sociais que se tornam referência, ou significado/significância na

\footnotetext{
${ }^{9}$ Entende-se por desemprego estrutural a não oferta ou possibilidade de trabalho.

10 As necessidades radicais, na visão helleriana, diz respeito àquelas necessidades criadas pelo próprio sistema capitalista que implicam a sua superação.
} 
medida em que introjetamos elementos constitutivos do outro ou da relação homem/natureza em nós: ao transformarmos a natureza por meio do trabalho, transformando-nos concomitantemente, conforme os enunciados marxianos e marxistas. O trabalho, portanto, aparece como a categoria fundante do ser social.

Deste modo, se o trabalho se apresenta alienado e mercantilizado, assim como todas as relações sociais, o indivíduo social incorpora essa lógica e se apresenta na vida social enquanto elemento coisal e objetual.

Quando as relações sociais parecem estranhas a sua natureza, ou seja, relações entre coisas - mercadoria - estas se apresentam fetichizadas, passando a ter uma relação de mercado a-humana. Quanto mais uma sociedade apresenta formas coisais entre pessoas, maior é o grau de alienação dessa sociedade - tanto maior é, assim, o grau de reificação.

A circunscrição fundamental do fetichismo é a supressão das mediações sociais, subsumindo-as a mera substância coisal e autônoma. No estágio atual do capitalismo, as coisas em si assumem uma valoração substantiva, inerente ao seu valor real, por exemplo, a posse de meras mercadorias representa um status de poder ou de socialização - a vida em sociedade fica condicionada ao ter e não ao ser.

Na sociedade regida pela lógica do capital, homens e mulheres passam a utilizar do outro como mero meio, como instrumento para as suas necessidades, mas não só o outro é utilizado dessa forma, mas, sim, a própria existência torna-se um meio e não a essência da vida. O imperativo categórico kantiano aqui é totalmente revogado. Todos os atributos da vida humana são transmutados em sua forma de mercadoria ou coisa. O valor monetário passa a ser condição sine qua non de toda a existência: lazer, trabalho, tempo, sobrevivência, vida social, por fim, a vida por inteiro passa a ser reduzida à dimensão de lucratividade ${ }^{11}$.

Nesse sentido, segundo Netto (1981, p. 5657), a manifestação da vida (Lebensäusserung) passa asera alienação da vida (Lebenstäusserung). Aalienação é uma forma específica e condicionada de objetivação do ser social no cotidiano.

\footnotetext{
${ }^{11}$ Produção de valor-de-troca - mercadoria.
}

A vida cotidiana alienada, regida pela lucratividade, mercantilização e imediaticidade, anula as possibilidades de consciência, por conseguinte, expressa um modo de ser altamente destrutivo e perecível: "[...] o cotidiano é o campo dos mecanismos de adaptação, e a luta não é a regra" (IASI apud MARICATO, 2013, p. 43).

A consciência reificada, subsumida à sociabilidade do capital, interioriza e reproduz a naturalização do pauperismo e a imutabilidade das condições impostas por essa lógica:

[...] nossa consciência imediata assume uma forma particular da realidade como se fosse a realidade, que sempre dói e sempre será assim. Navegamos nas diferentes esferas que compõem a vida de forma fragmentária e superficial, e não como totalidade articulada. 0 real se apresenta como uma impossibilidade (IASI apud MARICATO et. al., 2013, p. 42).

Por conseguinte, se o modo de ser está condicionado a um estado alienado/alienante e estranho em sua natureza, sua afirmação - sua ação - na vida social também se apresenta prejudicada, portanto, nega-se a possibilidade ética e política, nega-se a possibilidade de revolução.

Se o ser social se vê ou se apresenta como coisa, como mercadoria, como algo descartável, não-humano, como pode ter ações revolucionárias? Como pode assumir compromissos, atitudes, posicionamentos, responsabilidades, lutas sociais, vida social ética e política? Como pode ter ou apresentar uma práxis revolucionária, consciente, constitutiva e constituinte? Como pode lutar pelos seus direitos, reivindicar melhores condições de vida, maior atenção do Estado e participar da formulação, promulgação, avaliação e monitoramento das políticas públicas?

É evidente que as formas de manifestações expressam essa explosão descontrolada e aparentemente caótica de se expressar e reivindicar. Nas análises de Marilena Chauí (2013) sobre as manifestações brasileiras de junho de 2013, a "explosão do inferno urbano", a má qualidade ou não existência dos serviços públicos e o avanço desenfreado da especulação imobiliária e das empreiteiras que não têm um compromisso com o social e nem com o público foram o estopim para acender o barril de pólvora que a população vem vivendo em todos os grandes centros, porém, "[...] se nosso mundo urbano foi imaginado e feito, então ele 
pode ser reimaginado e refeito" (HARVEY apud MARICATO, 2013, p. 33).

Nesse caminhar, a categoria propriedade privada se apresenta como uma forma de alienação. É sabido que essa categoria surge num momento histórico em que o ser social delimita algo ou alguma coisa como sendo exclusivamente seu - aquilo-que-é-meu -, eliminando o caráter social das coisas ou pessoas - aquilo-que-é-nosso.

Como se vê, há uma implicância de valor às coisas, às situações e às pessoas. A categoria valor, aqui, tem um caráter altamente ontológico. $\mathrm{Na}$ sociedade individualista, aquilo-que-é-nosso praticamente é eliminado, partindo a valer somente aquilo-que-é-meu, nesse sentido, no âmbito da mercantilização, da lucratividade, da competitividade e da imediaticidade o aquilo-que-é-nosso ou o para-nós é totalmente aniquilado, até mesmo no corporativismo essa categoria se apresenta em sua forma unitária e unilateral, expressando também o fenômeno objetual e coisal.

Tendo em vista o caráter distintivo da sociedade atual, que apresenta um estágio de alienação altamente generalizado, podemos dizer que "[...] a autonomia dos indivíduos é puramente ilusória", homens e mulheres apresentam-se "subordinados a mecanismos e processos que não controlam e sequer reconhecem como oriundos das suas próprias relações". (NETTO, 1981, p. 69).

A escravidão dos indivíduos resulta tanto do fenômeno objetivo da exploração econômica (de que a propriedade privada é o índice mais evidente) quanto da internalização psicossocial dos efeitos dela decorrentes, cujo resultado é a sua desvinculação do todo da sociedade, do todo da existência social enquanto são agentes sociais particulares. (idem, ibidem).

Netto (1981, p. 81) aponta que "enquanto a organização capitalista da vida social não invade e ocupa todos os espaços da existência individual", há ainda um campo de manobra ou jogo em que se pode exercitar minimamente a autonomia e o poder de decisão, no qual é acessível um âmbito de retotalização humana que compensa e reduz as mutilações e o prosaísmo da divisão social do trabalho, do automatismo que se exige e se impõe.
Porém,

[...] na idade avançada do monopólio, a organização capitalista da vida social preenche todos os aspectos e permeia todos os interstícios da existência individual: a manipulação desdobra a esfera da produção, domina a circulação e o consumo e articula uma indução comportamental que penetra a totalidade da existência dos agentes sociais particulares, é o inteiro dos indivíduos que se torna administrado, um difuso terrorismo psicossocial se destila de todos os poros da vida e se instila em todas as manifestações anímicas e todas as instâncias que outrora o indivíduo podia reservar-se como áreas de autonomia (a constelação familiar, a organização doméstica, a fruição estética, o erotismo, a criação dos imagináveis, a gratuidade do ócio etc.) convertem-se em limbos programáveis. (idem, p. 81-82).

Cremos que estamos mergulhados por inteiro nesse universo reificado e feitichizado, mas será, então, verdade, que chegamos ao "fim da história" fukuyamiano? Acreditamos que não, pois ainda há brechas para que possamos reverter essa condição, porém, as possibilidades muitas vezes aparecem como utópicas, no sentido de algo idealizado e sem possibilidade de realização. Mesmo que assim pareça, ainda é uma crítica a esse modo de vida contemporâneo e alucinante.

\section{Considerações finais}

A vida cotidiana é essa fruição, justaposição de objetos, substâncias, implementos, circunstâncias, dinamismo, extremismo, contradições ou, como dizem os pós-modernos, essa ambivalência: homem e mulher na cotidianidade são atuantes e fluidores, ativos e receptivos, "mas não têm nem tempo nem possibilidade de se absorver inteiramente" (HELLER, 2004, p. 17-18).

Tal é o estado de subserviência aos apelos e apetites do capital que os aspectos mais prementes da hominização passam a ser representações alienadas e alienantes. Desse modo, não se consegue assumir um estado de consciência social que implique numa ação revolucionária ou numa consciência coletiva ética e política organizada para buscar novas formas democráticas, justas e de emancipação para a 
vida em sociedade, ou seja, buscar uma nova sociabilidade.

Torna-se necessário desmanchar os elos que nos prendem a essa cadeia de submissão. Tal é o "papel" do agente revolucionário, seja ele coletivo ou individual. Mesmo sendo individual, o para-nós deve estar implícito em-si-mesmo ${ }^{12}$ e para-si-mesmo ${ }^{13}$.

Heller (2004), ao se referir as teses marcuseanas, demonstra que conquistar o poder, fazer desaparecer a miséria e a opressão e reorganizar a economia estavam na ordem do dia enquanto exigências necessárias à reorganização da sociedade, porém, estas, por sua vez, não passaram de "revolução da fome", em outras palavras, de revoluções que visavam sanar apenas as necessidades básicas e imediatas.

[...] A situação atual é completamente diversa. Em primeiro lugar, as tragédias e os horrores do passado mostraram o que pode acontecer quando a moral, a escala dos valores morais, desaparece da esfera da política e é separada do esforço de humanização, o que pode acontecer quando a iniciativa individual desaparece em todos os níveis e a responsabilidade individual deixa de existir. [...] Já não se trata de criar as condições elementares para a vida humana e depois chegar a uma vida verdadeiramente humana: o nosso objetivo imediato é, desde logo, chegar efetivamente a esta última. A consciência do direito a uma vida verdadeiramente humana está presente nos homens, potencialmente, da mesma maneira como a consciência do direito à satisfação das necessidades mais primárias se acha presente nos homens na época das "revoluções da fome" (HELLER, 2004, 116-117).

Não é somente reivindicando contra o aumento das passagens de ônibus, por melhores condições de vida, por serviços de qualidade, contra os gastos em grandes obras para megaeventos, moralizando os políticos e as políticas, revendo as representatividades políticas, a participação na gestão pública, na eliminação de qualquer instância institucional, enfim, reduzindo a questões imediatas, fragmentárias, minima-

\footnotetext{
${ }^{12}$ Consciência de si mesmo; de sua condição de individualidade (de ser social).

${ }^{13}$ Consciência para além de si mesmo; implica em assumir a atitude e de se colocar como sujeito revolucionário.
}

listas e fundamentalistas, mas, sim, torna-se necessário e urgente mudar radicalmente esse modelo de sociabilidade.

A crise atual não está restrita somente ao campo da moral, da ética, da política, da economia, da cultura, do social ou até mesmo do campo espiritual, a crise atual se restringe a um modelo que esgotou a suas possibilidades de superação ou de reformas do capitalismo.

Os protestos nas ruas implicam na reconstrução das velhas utopias, na retomada de antigas ideologias, na releitura dos velhos enunciados, mas devemos estar alertas para que estas manifestações sociais não se tornem manifestações do espontaneísmo enquanto valor universal. Parafraseando Heller (1983, p. 31), ao dizer que "[...] toda filosofia oferece uma forma de vida; toda filosofia é a crítica de uma forma de vida e, ao mesmo tempo, sugestão de uma outra forma de vida", afirmamos, que toda manifestação oferece uma nova possibilidade; toda manifestação é uma crítica a uma forma de realidade e, ao mesmo tempo, sugestão para uma nova realidade.

[...] A ética marxista é uma práxis, não pode existir sem uma realização prática, sem se realizar na prática de algum modo. [...] Uma ética que se limita a contrapor-se passivamente ao atual mundo manipulado não passará de uma nova expressão, contemporânea da "consciência infeliz". A ética marxista só pode ser a tomada de consciência do movimento que se humaniza a si mesmo e humaniza a humanidade. Por isso, a ética marxista não depende só da compreensão e da aplicação correta dos textos de Marx: ela depende muito mais do desenvolvimento do movimento que a adote como moral (HELLER, 2004, p. 121).

A partir do momento em que os indivíduos conscientes produzirem possibilidades e se elevarem acima do reino animal e da alienação da vida cotidiana e da lógica capitalista, abrem-se as portas para o processo de humanização e emancipação dos sujeitos sociais e quiçá, uma nova sociabilidade.

\section{Referências}

ABBAGNAMO, N. Dicionário de Filosofia. Trad. da $1^{\text {a }}$ ed. Brasileira coordenada e revista por Alfredo Bosi e revisada por Ivone Castilho Benedetti, $5^{a}$ ed. São Paulo: Martins Fontes, 2007. 
BARROCO, M. L. S. Ética: fundamentos sóciohistóricos. São Paulo: Cortez, 2008. (Biblioteca Básica do Serviço Social; v. 4).

Ética e Serviço Social: fundamentos ontológicos. $3^{\mathrm{a}}$ ed. São Paulo: Cortez, 2005.

CARVALHO, M. C. B.; NETTO, J. P. Cotidiano: conhecimento e crítica. $8^{\mathrm{a}}$ Ed. São Paulo: Cortez, 2010.

CFESS. Serviço Social de olhos abertos para a educação: ensino público de qualidade é direito de todos/as. Disponível em: http://www.cfess.org. br/arquivos/cfessmanifesta_diadoAS2012-site.pdf. Brasília: CFESS. Acesso em: 15 de maio de 2012.

CHAUI, M. A revolta urbana. Entrevista concedida a NABUCO, A.; VASCONCELOS, F.; PRIMI, L.; NABUCO, W. a Revista Caros Amigos, ano XVII, ${ }^{\circ}$ 197, agosto, 2013. São Paulo: Caros Amigos, 2013, p. $10-14$.

IAMAMOTO, M. V. Serviço Social em tempo de capital fetiche: capital financeiro, trabalho e questão social. $3^{\text {a }}$ Ed. São Paulo: Cortez, 2008.

HARVEY, D. et. al. OCCUPY: movimentos de protesto que tomaram as ruas. Trad. João Alexandre Peschanski et. al. São Paulo: Boitempo, 2012.

HELLER, A. O Cotidiano e a História. Trad. Carlos Nelson Coutinho e Leandro Konder. São Paulo: Paz e Terra, 2004.

Teoría de las necesidades en Marx. Trad. J. F. Yvars. Prólogo de P. A. Rovatti. Barcelona: Península, 1986.

A filosofia radical. Trad. Carlos Nelson Coutinho. São Paulo: Editora Brasiliense, 1983.

Para mudar a vida: felicidade, liberdade e democracia. Entrevista a Ferdinando Adornato. Trad. Carlos Nelson Coutinho. São Paulo: Brasiliense, 1982.

La revolución de la vida cotidiana. Trad. Gustau Muñoz, Enric Pérez Nadal e Iván Tapia. Barcelona: Península, 1982.

Sociología de la vida cotidiana. Trad. J. F. Yvars e E. Pérez Nadal. Barcelona: Península, 1977.

JUNQUEIRA, M. F. P. S.; DESLANDES, S. F. Resiliência e maus-tratos à criança. Caderno Saúde Pública. Rio de Janeiro, jan-fev, 2003. Disponível em: http://www.scielo.br/pdf/csp/v19n1/14923.pdf. Acesso em julho de 2013.
LEFEBVRE, H. Marxismo. Trad. William Lagos. Porto Alegre: L\&PM, 2009. (Coleção: L\&PM Pocket, v. 784).

LUKÁCS, G. Introdução a uma Estética Marxista. $2^{\text {a }}$ ed. Trad. Carlos Nelson Coutinho e Leandro Konder. Rio de Janeiro: Civilização Brasileira, 1970.

Prefácio. Em HELLER, A. Sociología de la vida cotidiana. Trad. J. F. Yvars e E. Pérez Nadal. Barcelona: Península, 1977, p. 09-14.

Ontologia do ser social: os princípios ontológicos fundamentais em Marx. Trad. Carlos Nelson Coutinho. São Paulo: Ciências Humanas, 1979.

LUKÁCS, G.; SCHAFF, A. Sobre o conceito de consciência de classe. Trad. Patrícia Boanova e M. Amaral. Porto: Escorpião, 1973. (Cadernos: O homem e a sociedade).

MARICATO, E. et. al. Cidades Rebeldes: passe-livre e as manifestações que tomaram as ruas do Brasil. São Paulo: Boitempo: Carta Maior, 2013.

MARX, K. Grundrisse: manuscritos econômicos de 1857-1858, esboço da crítica da economia política. Trad. Mario Duayer; Nélio Schneider. São Paulo: Boitempo; Rio de Janeiro, Ed. UFRJ, 2011.

O Capital: crítica da economia política. Livro I, Vol. I. 24ª ed. Trad. Reginaldo Sant'Anna. Rio de Janeiro: Civilização Brasileira, 2006.

Para a Crítica da Economia Política. Trad.

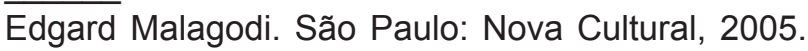
(Coleção: Os Pensadores).

Manuscritos Econômico-Filosóficos. Trad. Jesus Ranieri. São Paulo: Boitempo, 2004.

MERLINO, T. O golpe de Estado dos latifundiários. Caros Amigos. São Paulo: Casa Amarela. Ano XVI. $N^{\circ} 184$, julho 2012, p. 16-18.

NABUCO, A. A guerra instalada no mundo virtual. Caros Amigos. São Paulo: Casa Amarela. Ano XVI. No 184, julho 2012, p. 39-43.

NAGOYA, O. "Não teremos mais paz econômica". Caros Amigos. São Paulo: Casa Amarela. Ano XVI. № 184, julho 2012, p. 20-22.

NETTO, J. P. Uma face contemporânea da barbárie. Texto da comunicação de José Paulo Netto na seção temática: "O agravamento da crise estrutural do capitalismo. O socialismo como alternativa à barbárie", no III Encontro Internacional "Civilização ou Barbárie". Sepre, $30-31$ de outubro $/ 1^{\circ}$ de novembro de 2010. Disponível em: pcb.org.br/portal/docs/ 
umafacecontemporaneadabarbarie.pdf. Acesso 10 de fevereiro de 2012.

Cinco notas a propósito da "questão

social”. Em Revista Temporalis. Ano 2, n. 3, jan/jul, 2001. Brasília: ABEPSS, Grafine, 2001, p. 41-49.

Capitalismo e reificação. São Paulo: Ciências Humanas, 1981.

NETTO, J. P.; BRAZ, M. Economia Política: uma introdução crítica. $2^{a}$ ed. São Paulo: Cortez, 2007. (Biblioteca Básica do Serviço Social, v. 1).

SÁ, Eduardo; JÚNIA, Raquel. "A Cúpula dos Povos foi anticapitalista". Caros Amigos. São Paulo: Casa Amarela. Ano XVI. № 184, julho 2012, p. 34-36.

VERONEZE, R. T. Agnes Heller, indivíduo e a ontologia social. Dissertação de mestrado apresenta ao Programa de Pós-Graduação em Serviço Social da Pontifícia Universidade Católica de São Paulo. São Paulo: PUC/SP, 2013.

VICKY, A. Soldados africanos para as guerras norte-americanas. Le Monde Diplomatique - Brasil, São Paulo: Palavra Livre. Ano 05. № 60, julho 2012, p. 21-23.

ZINET, C.; MONCAU, G. Grécia ensina: não há austeridade sem resistência. Caros Amigos. São Paulo: Casa Amarela. Ano XVI. № 184, julho 2012, p. 10-13. 